\title{
Half Arab, Half American: Searching for Cultural Roots in Mona Simpson's The Lost Father (1992)
}

Riham Fouad Mohammed Ahmed*

Department of English Language and Literature, Faculty of Arts, Aswan University, Egypt

Corresponding Author: Riham Fouad Mohammed Ahmed, E-mail: rfahmed@syr.edu

\section{ARTICLE INFO}

Article history

Received: September 14, 2018

Accepted: November 19, 2018

Published: February 28, 2019

Volume: 10 Issue: 1

Advance access: January 2019

Conflicts of interest: None

Funding: None

\begin{abstract}
This paper investigates the effect of being culturally hyphenated in the formation of identity as represented in Mona Simpson's The Lost Father (1992), in which the female protagonist is an Arab-American who belongs ethnically to Arab culture and culturally to American one. Because of the absence of her father, she knows nothing about her homeland (Egypt) and/or Arab culture. The protagonist has only slight and superficial image on Arabs derived from TV and her racist grandmother. This hazy background on Arabs makes her unable to identify her own cultural space, so she decides to travel to Egypt to make a journey of self-discovery. During her journey, she is disappointed in more ways; her father is not like what she thinks, and Egypt is not the best place for her. However, she, there, discovers her true self and searches for the true image of Arab culture and traditions away from imposed American representations, stereotypes, and labels.
\end{abstract}

Key words:

Broken Families,

Absence,

Cultural Duality,

Arab-American,

Self-Discovery

\section{INTRODUCTION}

I am not a foreigner with adventures to tell and I am not an American,

I am one of the children with a strange name, who cannot choose a

culture. I must always live in between. (Abinader 11).

The above quoted extract illustrates the main goal of this paper which is tracing the status of having a hyphenated identity. It aims at focusing on the discovery or re-discovery of self throughout searching for the absent father as a key to her homeland's traditions. Mayan Atassi, the protagonist of Mona Simpson's The Lost Father is a good representative for this cultural duality dilemma, because she is in a keen search for discovering her conflicting cultural identities and understandings. The protagonist is an Arab-American who is an American born. She tries to discover her own identities, to create her new concept of home(s), to develop her Arab-American consciousness, and to craft other tools of negotiating her own binary opposition, and peculiar hyphenated identity of life through facing her cultural duality or juxtaposition (Jarmakani 241). Does home-for her- mean her new own spaces where she can freely express her own self, smoothly make an integration between homeland and newly adopted land, and can easily live her own creative space away from being alien or being the other American in homeland and the other Arab in America (Abdelrazik 2)? This creative space between two distinctive cultural heritages or hyphenated identities is also called "interstics," or "third-space" (Bhabha 224). Mayan's own feelings of absence of main values in her life turn her to be an explorer for truth and reality. She experiences a triple thought of sufferings; absence, longing, and determining the degree of belonging. Her journey is to discover the truth of absence in her life may be seen as a kind of cultural journey. In her search, Mayan traces the hazy image of father and the ambiguous concept of home. Unfortunately, she has an experience of disappointment and frustration. All these mixed experiences may have an influence on forming, shaping, and developing peculiar cultural consciousness of her hyphenated identities as Arab-American.

So, this case of double consciousness, cultural duality, and hyphenated identity may be described as "an in-between state in which Arab Americans are not quite Arab according to their ethnic brethren in the Arab World and not quite American according to their co-national peers in North America" (Salaita, "Arab American Literary Fictions" 124). As a result, this character may be seen as not completely Arab or purely American. So, Mayan may be seen typically as a vivid pattern of what is so called ethnic dilemma. 
This kind of self-identified narratives is a result of a wide public American demand to explore and know more about Arabs, Arab-Americans, and Muslims directly from those who have Arab descents, especially, after the 9/11 attacks. So, Mara Naman ${ }^{1}$, an Arab-American critic, considers the relationship between what she called "ethnic currency and the profile of the American "literary" writer in the contemporary publishing market"(Naman 364). As Western readers have a certain image of stereotyping of Arab women, actually they have a list of "eternal grievances of the Arab women: the veil, polygamy, clitoridectomy, claustration, virginity, forced marriage, frequent births, repudiation, and beatings" (Amireh 186). All these stereotyping representations come into the mind of western society while talking about Arab woman. So, Mayan has a double thought of suffering being Arab and woman at the same time.

One of the first Arab-American novelists and essayists who respond to the American public demand to know more about Arabs, and achieve commercial success is Mona Simpson. She was born in 1957 in Green Bay, Wisconsin to an American mother and a Syrian father. Her real name is Mona Abdul Fattah Jandali. After the departure of her father, Mona was given the family name of her stepfather, Simpson. She is currently a professor of English at the University of California, Los Angeles (UCLA). She published six novels: Anywhere But Here (1986); The Lost Father (1992); A Regular Guy (1996); Off Keck Road (2000); My Hollywood (2010); and Casebook (2014). Her work reflects certain themes of cultural duality which is clearly seen in the sense of social disturbances (like absent father and outlaw mother), and broken families.

Simpson won a lot of awards such as: Whiting Prize (1986); Hodder Fellowship (Princeton University) in (1987), Guggenheim Fellowship (1988); Lila Wallace Readers Digest Fellowship (1995); Chicago Tribune Heartland Prize (2001); Finalist: Pen/Faulkner Award (2001); Literature Award from the American Academy of Arts and Letters (2008). Moreover, she has an episode in TV. Series that is entitled "The Hidden Room" (1991). She also had a special appearance in Charlie Rose program (2013).

Simpson>s Anywhere But Here delineates the story of Ann and her mother Adele. Ann is abandoned by the father who turned up to be Egyptian. She is raised by her American mother Adele. Both Adele Diamond and her Ann seek the American dream of richness and superficial appearances. So, they are running away from their family in Wisconsin to Los Angeles with hopes of superficial appearances for Ann and a rich husband for Adele. Ann may be regarded as the center of Arab-American dilemma. At the very beginning, she tries to assimilate the American culture seeking the American dream, and later on she turns to be in a search for her true identity in The Lost Father.

Her The Lost Father tackles the idea of searching for the self by exploring roots. Mayan Atassi, a twenty-eight years old medical student, searches for her Egyptian father who has abandoned her and her mother in Michigan in 1960s. Mayan wants to answer the question; why her father left without bothering to make any contact with her? She even travels to Egypt to find her father who always told her «Don»t forget I am your father. Nobody else can never be that» (The Lost Father 138). She hopes her lost father resembles the Palestinian leader Yasser Arafat.
A number of critics treats Simpson's work as a part of contemporary American (mainstream) or Arab-American fiction. Carlton Smith and Deborah Paes de Barros are two of these critics who analyze her work in their article "Singing in the (Post-Apocalyptic) Rain: Some High/Low Notes on Post/postmodernism and Contemporary American Fiction," that was published in American Studies International, Vol. 33, No. 1 (April 1995). They assume that she is fond of social themes like broken families, collapse in family values, alcoholic and/or careless parent, abused children, the meaning of home(s) to a hyphenated person or a culturally dual American, especially to an Arab-American girl. Thus, Mona Simpson often addresses the theme of home(s) and family as icons of identity that she searches, and united self that she seeks in her fiction:

The family is reconfigured. Single mothers, disassociated siblings, and alcoholic relatives abound. Home is no longer a fixed concept; characters live in their cars, in trailers, apartments, and in the temporary shelters offered in this new world order. There is little stability. (Smith 4)

Moreover, Steven Salaita, an Arab-American critic and university professor, in his Modern Arab American Fiction: A Reader $>$ S Guide illustrates this theme of Arab-American social disturbances and family collapse. He states that "one major aspect of the novel in this vein concerns the collapse of the nuclear family, exemplified by the theme of the absent father" (Salaita 22). Simpson has a certain social literary line of nostalgia and diaspora. It may be seen that she tries to be more associated with Arab-American themes of duality, ethnicity, and hyphenation in The Lost Father.

Mona Simpson's fiction is mainly marked by the presence of ironic nostalgia, loss, and even regret. For example, her The Lost Father (1992) tackles the idea of searching for the self by exploring roots. Mayan's search, in The Lost Father, is not only to find her father or to explore her homeland, Egypt, but also to discover self. Here, both father and Egypt are regarded as icons of identity, self-fulfillment, and self-unity.

This novel may be seen as a sequel or a supplement to her first novel Anywhere But Here (1986), which portrays the story of a mother-daughter relationship and/or the American dream. Unlike Anywhere But Here, The Lost Father, deals with a father-daughter relationship, and the plight of cultural identity and self-discovery. Simpson published the first part of this novel in The North American Review (Jun. 1986). This part presents the cagey and problematic mother-daughter relationship of Adele and Ann (57). Then the whole novel was published by Alfred A. Knopf, Inc in the same year. Mona Simpson's Anywhere But Here presents "the conflicted characterization and literary space of the mother outlaw/vagrant" (Smyth iii). Afterwards, the text turned to be a famous movie under the same name, starring Susan Sarandon (Adele August) and Natalie Portman (Ann August). The story tackles mother's and daughter's journey towards "self- definition" (Heller 164). This journey may be seen as seeds of her next journey to Egypt to discover her united self. In Anywhere But Here, the protagonist (Ann) has only a weak trial of searching for the absent father during teenage, this trial is checking telephone books of new cities. Nevertheless, there is no feeling of loss to the absent father. Unlike Ann, Mayan's sense 
of loss and belonging in The Lost Father takes her to Egypt to discover self and others. So, Anywhere But Here may be regarded as a seed of The Lost Father.

In The Lost Father, the protagonist Mayan, has a double thought of suffering which is being fatherless and alone despite the presence of her mother. She needs her father's safety and warmth, and misses her mother's care and passion at the same time. Definitely, the impact of father/mother loss on Mayan is undeniable. It seems that she suffers both the abuse of father-daughter relationship and neglecting or indifference of mother-daughter relationship. Thus, these two broken relationships have a negative impact on her psyche, identity, and consciousness at the very beginning. Nevertheless, they turned to be a positive energy and a pushing urge to find her unified self. During her adolescence, Ann (who turns to be Mayan) suffers a "rocky life with her nearly psychotic mother" (Smith 4). Ann and her mother's journey may be interpreted as a search for the American dream:

Together, like millions of mother and daughter teams before them, they travel to California hoping to discover stardom (or, minimally, a rich father). As in nearly all such tales, the streets do not glimmer with gold, and the few tenable dreams that find some fulfillment appear banal. But in some strange way, while nearly vitriolic in places, Anywhere But Here is ultimately about the eerie quality of maternal love. In its deconstruction of affection, the novel reasserts the daughterss bond with the mother. (Smith 4)

Then, as an adult she has another kind of sufferings; losing her father and missing her mother on one hand, and on the other, her hyphenated identity and dual culture. In The Lost Father, Simpson investigates a certain quest to be fulfilled which is finding the lost father and exploring her Arab identity at the same time. The novel can be seen as a kind of a trial to set up or re-establish new relationships with self, homeland, culture, mother, new women friends, and even father. Mayan examines both self and others during her search for identity, unified, solid, and coherent self.

Mayan Atassi, a twenty-eight years old medical student, searches for her Egyptian father who has abandoned her and her mother in Michigan in the 1960s even without any caring to contact her or her mother later on. Mayan wants to find out: why her father left without bothering to make any contact with her. She even travels to Egypt to find her father who always told her "Don't forget I am your father. Nobody else can never be that" (The Lost Father 138).

In the course of her search journey, she finds her father and discovers that he is not worthy all her efforts of restless and keen search. Yet, she succeeds in breaking the barriers of race by admitting to everyone "I am half Arab" (505), without feeling inferior or exotic. Unfortunately, she does not meet the lost father who is the hero of her dreams, but she discovers her true self, and re-establish good relations with others including her parents. Simpson>s protagonist, Mayan Atassi, is regarded as a representative of the dilemma of Arab-American cultural duality. Throughout the consequence of events in the novel, Simpson >s protagonist is torn in-between Arab and American Identities.
At the very beginning, Mayan may assimilate the new adopted culture while the mother culture functions as a dim background, then she tries to discover her true self by being well oriented to her native culture. Firstly, she is "fragmented" and "obsessed with finding her father. This obsession becomes a symbolic and literal quest that takes her as far as Egypt," where she knows more about her native homeland, absent father, and unified self (Wittstein 4). Mayan attempts to be an Arab-American not purely an American. She tries to reach this far-fetching balance between being an Arab and an American.

Simpson's protagonist, Mayan Attassi, is an Arab-American who feels the sense of loss, absence, loneliness throughout the novel. For example, she states "absence has qualities, properties all its own, but no voice" (4). Moreover, she tells us "all you have to do to become somebody's God is disappear" (38). There is a kind of emphasis on such a sense of loss by repeating thoughts and words: Mayan repeats these words "disappearing was all you had to do to become somebody's god. And maybe being found was all it took to be mortal again" (444). Throughout the novel, Mayan always remembers her sense of loss and even documents it by the repetition of words like; absence, disappear, disappearing, and mortal, this repetition which emphasizes her sense of absence and supports her profound feeling of loss. This "repetition of thought may be justified by Mayan's absolute obsession with her search" (Phillips 469).

Mayan has a double thought of a bunch of sufferings, because of her experiences of sense of loss, absence, longing to an absent father and a vague homeland, on the one hand, and on the other her wish for a regular family "we believed he would come back and make me a daughter again, make my mother a wife" (5). Actually, she freezes her life, and puts off her study and even love to search for her lost father.

As a young child

when Home

was where you lived

and where-are-you-from?

was more about your parents

"Home," My Name on His Tongue (Halaby 23)

In these lines, Laila Halaby, the Arab-American novelist and poetess, confirms the argumentative concept of home(s) to the Arab-Americans. Undoubtedly, cultural duality and identity crisis are plights that begin very early in American diaspora. In the same way, Mayan as a hyphenated child is always asked for her homeland and parent. So, she tries to put answers for the afore-mentioned question. The above question is raised in both the soul and the mind of Simpson's protagonist. She asks where is home? Is home the place in which one lives or can home be seen as one's native homeland? Or may it be a larger concept of belonging to two binary oppositions? For a young child, home can be seen through the cultural, ethnic, and national belongings of parents. It is not an easy task to explore home(s) when you even do not know the place of one of your parents (father), or even know nothing about his homeland (Egypt). To be an Arab-American, culturally hyphenated, and mixed gendered with strange names is an experience worthy of note. If Mayan ignores the absence of her father; she cannot skip the strange Arab 
names next to hers, or neglect the truth that she is half Arab. She has to answer questions like; "so does your dad own a 7-Eleven or an oil well? Do you have camels in your backyard? Does your dad beat your mom?" or she may be called "Towel head" and "camel jockey" (Naber 301). In this sense of cultural duality and hyphenated ethnic consciousness, Simpson's Mayan tries to put answers for these questions. This paper is to consider cultural diaspora as a way to find and/or re-establish self-determination/definition. So, Mayan thinks and lives out of the box (communities' restrictions or others' concepts). In other words, her story is a trail to see beyond the imposed frames.

\section{SENSE OF LOSS AND MISSING AS A MOTIVATION FOR DISCOVERING ROOTS}

The opening pages of this novel function as a description of senses, feelings, and thoughts that are mixed together to portray an acute sense of loss and longing at the same time. Loss for all of them: a daughter who is waiting for her father, a wife who is waiting for her husband or even some other man who can do it, and even a grandmother who is waiting for the happiness of her daughter and granddaughter. They are all waiting for various reasons with a different sense of loss. There is a kind of hierarchical order of loss. For example; Mayan possesses the greatest portion of loss, then the mother who has the second rank. Mayan herself asserts, "There were two of us who were his" (3). Finally, the grandmother comes last as she has the lesser sense of loss and longing.

For the grandmother, twice within the first three pages of the novel we as readers are informed that Mayan>s grandmother does not like the absent father, she even considers him as dead just like her husband (3-5). Mayan tells, "My grandmother respected our feelings although she had never liked my father" (3). Simply, she does not like him, so she is not eagerly await for his return. She only respects the feelings of her daughter and granddaughter. Her own sense of loss and absence may be for the loss of the happiness of her daughter and granddaughter. Mayan's grandmother may be regarded as the American figure who does not like foreigners, knows nothing about their homelands, and does not care about their inferior cultures, and even she considers non-Americans as others. "Egyptians and Egypt are outrightly otherized in the novel" (Naman 365). Moreover, Mayan lives in the midst of an American society that considers Arabs as exotics and an invisible minority and Arab names as unpopular ones. All these elements are a kind of obstacles that interrupt her keen search and as an urge for searching at the same time.

Mayan's mother, however, longs for a family reunion with the home coming of her lost husband. Her plight is not only the sense of loss and absence, it is also sticking to hope and expectation. She wastes a lot of time waiting for him, expecting him to come back, and longing for his return. Mayan describes her mother's sense of loss and longing:

My mother is fifty-six years old and in a way she still believes. She would say she does not but she saved herself for him, saved herself beyond saving, to a spoiled bitter that expects only the worst. But her private soul she is a child holding an empty glass jar waiting for the sky to fill it, for him to return and restore to us our lives. (3)

She waits for a long time till being 56 years old. Her only wish is to restore her life and her daughter's normal life. Both await for him to inspirit their feelings, to revive their emotions, and to heal their souls. After father's absence, Mayan and her mother are turned from the "original" to the "general" from waiting this absent father to believing that another man would come and be an alternative husband and/or father. Unlike Mayan, however, her mother has an alternative option: choosing another man to play the role of a husband:

My mother never lost her faith in men, but after years, it

became more general. She believed a man would come and be my father, some man. It didn't have to be our original one, the one we'd prayed to first as one and only. Any man with certain assets would do. (5)

Here Mayan confronts the absence of a lost father, and a caring mother, and a xenophobic, racist, and culturally superior grandmother at the same time. Simply, she was born out of her place or her homeland as a fatherless daughter and of a single parent. Mayan is completely alone because she is implanted in a foreign land with Arab names or she is "blanketed in foreignness" (Halaby, "The Journey" 9). This sense of loneliness and foreignness adds to her acute sense of loss.

Mayan's sort of waiting is totally different from her mother's or grandmother's because she is not only searching for a father but actually she is trying to search for an icon of identity and for her roots. She is eager to discover her native culture in order to explore her own self. For her there is not an alternative option. Mayan herself confirms the urge of her keen search; it is not a kind of leisure or an entertainment rather it is a must for her identity, consciousness, and true self: "everyone knew I wanted to find my father. That was something of mine always" (299). Her desire to "find and especially to know her father is obsessive in the extreme. She puts off marriage, career and any real commitments" (Orfalea 130).

As a fatherless daughter, Mayan is unable to achieve self-fulfillment and experiences "emotional confusion and difficulties with love relationship" (Wittstein 55). On the other hand, "fathered-daughters are given an underpinning of support that allow them to dare, a confidence in their femininity and ability to achieve" (Wittstein 56). As readers, we are not informed throughout the story that she has a boyfriend or a love relationship. Subconsciously, she predicts the failure of any relationship she involves in while her father, her identity, and her true self are absent.

Mayan's search may be seen as stunning, serious, and sustainable because she even hires detectives to travel all over the States and even to Egypt itself. This penetrating search may be seen from two different perspectives: "the relationship of children to parents as well as ethnicity to self, and self to the universe" (Orfalea 130). Mayan considers being an Arab -half Arab- as invisible in the world, unpopular minority, and strange names. Mayan Atassi>s view point on ethnicity is a little bit harsh and tart:

I'd always been suspicious of ethnics. Especially those who like me, didnıt look it. I looked it a little but not enough that I couldn>t have been anything else. A Jew for instance, which to many Americans was like the 
absolute opposite. Indian maybe. Most Americans look like they could be a couple of things....I had a perverse streak. I liked to topple peopless pride. (390)

It seems that because of the Arab descent of the father, Mayan is considered one of these minorities in America; she is not typically like Arabs but she looks a little like them. She has lost her own link to this Arabic culture. So, she is not well oriented to Arab culture. Mayan herself states and admits «most of being Arab I learned from the movies» (394). Thus, her search is not only for a father but also for a culture and for roots. Mayan takes the decision to travel to Egypt whether she finds her father or not to know more about the unpopular Arab minority to explore her lost sense of culture (390). Simpson's Mayan illustrates why Arabs are regarded as an invisible minority in America. Simply, because they do not have their own box of ethnicity in U.S.A's checklists, so they have to check either Whites or Other in American official forms. She asserts:

There weren't many Arabs in America. Not a popular minority. On all the forms you filled out where it gave some kind of advantage to minorities, they listed about seven different kinds with little boxes for you to check, and Arab was never a box. I guess they considered it just white. Or other. Being Arab was not something you'd want to right away admit, like being a Cherokee or Czech. (389)

Here, Simpson focuses on an important and argumentative ethnic issue in U.S.A; classifying Arabs as Whites though not all Arabs are racially Whites, or other but they do not have a check box that refers to their real racial and cultural ethnicity. For example, all American official application forms do not contain a check box for Arabs. There is almost no space for Arab-Americans to feel their true ethnicity. An Arab identity is never a consideration "since most ethnic categories on American forms (and in American minds) do not include 'Arabs." ' On some personnel forms, the category "white" is defined to include peoples from the Middle East, though this definition is open to dispute" (Hoyt 47).

Laila Halaby's poem "Browner Shades of Whites" supports the same issue of ethnicity crisis that Mayan feels. She illustrates the feelings and challenges of an Arab girl who does not find her own check box of ethnicity in the American official applications. These applications always end up with a red end that omits the Arab origin as a minority in the U.S.A. As a result, she does not have an alternative unless checking the box "white" under race or ethnic origin. For Americans, She has more than one ethnic origin. For example, she may be White, Woman of color, or Caucasian. Her mother and friends understand her problem, but her so called democratic country that can solve this problem by adding one more box for Arabs, does not. In Laila Halaby's words:

Under Race/Ethnic origin

I check white

my friend who is Black

calls me a woman-of-color

my mother who is white

says I am Caucasian

my friend who is Hispanic/Mexican American understands my dilemma

my country that is a democratic melting pot

does not (204-5)

Both the novelist Simpson and the poetess Halaby confirm the problematic and argumentative ethnic issue that confronts Arabs in America in their works. Actually, Halaby wraps this issue up while concluding her poem; she presents the sympathy of all minorities and the indifference of the U.S government.

Hence, Mayan's decision to search into her cultural roots by traveling to Egypt may be regarded as a trial to see beyond the frame of ethnicity; to search for her father, to know more about her homeland, and/or to get rid of or to confirm what she knew from mother, grandmother, and even movies. Mayan >s journey is shaping her self-discovery, consciousness, and her own new space of identity. Mayan travels to Egypt to hear from two parts and to see the whole picture. Because «always in divorce, there are two sides to the story» (Orfalea 131). For example, her mother told her that their marriage broke up because her father did hate Mayan's noisy cries when she was a baby. Her father is not that bad and uncaring man she was told about. Mohammed Atassi has a different story about a young and rushing wife who turned their marriage to unhappy and miserable one. He complains that she never let him touch the baby or even kiss her. Moreover, Mayan's mother told some Egyptian-American relatives the worst things about her visit to Egypt and how it was a pessimistic and dusty place, and how dirty the people were (455). All her dashing acts enforce him to leave and disappear for decades. There is no wonder because Mayan knows that:

Over time he was still a man who had left his family and not tried to find us. I learned that people cannot be more or better than their lives. For one day they can. But everyday matters more. Love is only as good as days.

So, her father is overburdened by his own troubles more than by his interest in reconnecting with his daughter. She wishes her search to be worthy and her journey to be fruitful and successful so she highly expects the lost father to be a great man to justify her restless search in States and her long journey to Egypt. Unfortunately, her expectations do not meet the truth. Mayan was disappointed because her father does not resemble Yasser Arafat. More than once, she hopes her father looks like Arafat. She wishes "in my wilder moments I'd let myself think they were the same person" (453). Moreover, she hopes he may look like the Egyptian actor Omar Sharif, why not both of them are Egyptians (394). Unfortunately, she finds her father not like Arafat or Sharif.

Simpson helps her protagonist to confirm her sense of disappointment through the reiteration and repetition of a certain statement in more than one situation throughout the novel. She describes her father "he was only a man" (451). Then, she repeats "he was only a man with his own troubles who didn't manage to keep track of his wife and child. After all those years, I was wrong about him. He was only a man" (475). He is not the guilty absent father or even the great man she thought about, he is only a man that has half of the story and the other side of the coin. Now, she puts parts together in order to see the whole picture. After reaching this truth, she 
describes her father as a man, who is overcome by his own burdens and troubles more than by his wife and daughter, not as an Arab. She knows that "being Arab was not something to you>d want to right away admit" (389). However, after her journey of search to explore and find her true self, Mayan clearly admits "when people ask me, I say right away I'm half Arab" (505). She finds it easy to say to anyone who asks that she has an Arab origin and she is half Arab.

Although her name is Mayan Mohammed Atassi, she enters Egypt as Mayan Stevenson. Her religious identity is quite vague and disappeared. Throughout the whole novel, there is a slight mention of Islam only in three positions. It seems that both Mayan and her father just have Muslim names. For example, Mayan reads about Islam, for the first time, when she was on her way to Egypt. She states:

Anyway, there I was on the plane, an American wearing heavy black-framed sunglasses with the $E$ volume of the Encyclopedia Britannica open on my lap, reading the history of Egypt. I was reading about the Pyramids. After this came the $I$ volume for Islam. (390)

Because of her father's absence, Mayan is alienated from her native religion, knowing nothing about it, and taking her religious sources from the Encyclopedia Britannica not from performing Islamic practices by her father. Another minor mention of Islam is recorded in the text when she found her father, who tells her his own childhood memories with his stiff father especially in the holy Ramadan, the fasting month. However, the father mentions nothing about his current Islamic practices. Mohammed Atassi asserts:

But I still love my dad. I don't know why. I still dream about him years after he died. Basically he was a giver. As harsh as he was. When the holy Ramadan came on, he took us out to get everybody new suits and new shoes. Whatever. And he didn't care about any of that for himself. Shoes or clothes. But he was a stubborn guy. (465)

This above quoted extract refers to Mohammed Atassi's shallow knowledge of religion. The father just remembers his own memories in the holy Ramadan (fasting month of Muslims). But as readers, we are not informed that he has such memories with his daughter Mayan. Although he tells Mayan that "we were descended from the great prophet Mohammed," he does not even ask her whether she practices Islam or not, as simply they are not practicing Muslims (395). Consequently, they can be seen as a "lapsed Muslim" family (Naman 364). There are only three slight references of Islam from both father and daughter. Throughout her journey, Mayan gives us much more description of the current Egyptian political and social events at that time. Most famous sightseeing, ancient Egypt, the Nile, popular cuisines, and Egyptian movies are heavily more mentioned than religious places, icons, and practices. Both father and daughter only refer to their slight memories of Ramadan, ancestors' noble origin, and the I volume of the Encyclopedia Britannica about Islam. Hence, Mayan's search seems to be mainly for cultural roots only. Undoubtedly, the father and his homeland are main entrances to such culture.

Religion and language may be regarded as Mayan's main senses of loss because of her father's absence. Like her reading about Islam on the plane, Mayan knows nothing about
Arabic because her father had not taught her any Arabic except some words and mini dialogues she has learned so far on the plane from her "Arabic at a Glance phrase book that helps her during her visit to Egypt" (389). Her guidebook is "propped like a piece of music between two pronged fingers" (400). For Arabic language, Mayan informs us more than once that her guidebook helps her in some situations like booking a room in Alexandria, "Mumkin ahgiz ohda ghur-fa min hina?" (403), and introducing herself "my name is _- "ismee Mayan Atassi" (405). Simpson’s Mayan is in a keen search for the self and its relationship to others (parents-communities), to ethnicity, and to the whole universe. Mayan possesses a sort of cultural duality and double consciousness within her family's stories. Majaj comments on such familial stories:

Family stories frequently ground ethnic identification, and the popularized search for "roots" is often articulated as "remembering who you are." Memory functions on both a cultural and a personal level to establish narratives of origin and belonging. ("Arab American Literature and the Politics of Memory" 266)

Mayan searches for her Arab cultural roots. So, homeland (Egypt), history, familial ties and parental relationships are greatly taken into her consideration. Actually, Mayan Atassi has her own special parental experience ${ }^{2}$; she has not a regular family because she is a fatherless with a mother who does not care about her daughter's emotional and psychological development. Definitely, the absence of Mayan's lost father is not only her preoccupation. The mother, also, is unable or unwilling to provide her daughter Mayan with care and emotional support; she leaves Mayan with her grandmother for long time. Actually, the absence of a present mother (Lynn Cochran calls her "lost mother") (108), a grandmother who does not like the father, give her a vague, distorted, and subjective view points on the absent father on one hand and his homeland and culture on another.

Mayan seems to have an extraordinary relationship of carelessness with her family. This type of families presents an obstacle or a challenge for the protagonist to come over. As a result, Mayan tries to search for the minimal and normal care of parents, who are physically and/or emotionally absent or lost. She is suffering from a kind of paternal abandonment. This carefree category of parents simply has drifted out of their daughter's life, dreams, demands, and self-fulfillments. Here, parents are not emotionally cruel; simply they are not there to give love and emotional support for their daughters, even if physically present. Briefly, Mayan's quest takes her to her homeland "making a pilgrimage to Egypt" (Naman 371). Here, Mayan seems to mean pilgrimage with its cultural not religious concept. Mayan makes a purely cultural journey and gives us as readers nothing about her religious cult, beliefs, and practices.

The protagonist, Mayan, psychologically and emotionally confronts abuse/abandonment relationships with her parents. She discovers her self-realization by discovering self-identity, exploring home(s), testing communities' cultural norms, determining her demands and goals, and locating her own self in her new spaces which are made by struggling, searching, testing, and discovering away from 
others' domains, thoughts, beliefs, and traditions. Simply, she seeks "to establish new points of intersection within transnational spaces" between East and West, Arabness and Americanness, and self and other (Majaj "Introduction" $\mathrm{xxx}$ ). Mayan faces the main challenge of creating a new space that she can freely express her self-discovery. She is also crafting a new other space in which she can actually reflect her experience as an American and Arab at the same time. Her own new space of belonging depends mainly on recasting identity. Evelyn Alsultany asserts:

Identity must be reconceptualized so that we [Arab and Muslim] can speak our own identities as we live and interpret them in multiple contexts. But how can we create a space for the articulation of multiethnic identities as unitary and whole rather than fragmented and dislocated? (Alsultany 109)

\section{CONCLUSION}

Mayan's life can be seen as a chain of transformations, interactions, and intersections with others, concepts, and places, and cultures. Hence, Mayan thinks and lives out of the imposed areas. So, she can see beyond her own traditional frames. She has certain quest that her society cannot answer. During her journey, she found her disappointing father who is not like what she thinks, and knows more about her homeland Egypt. However, she can frankly say that she is "half Arab" instead of saying "American." She discovers her true self and searches for the true image of Arab culture and traditions away from imposed American representations, stereotypes, and labels. Thus, she begins to be in a keen search for model and logical answers for her questions. The answers put an end of her fragmented life, hyphenated identity, scattered soul, border crossing, and politics of exile and establish or re-establish a kind of confirmation to her unity of bicultural contexts, and solidarity of self at the same time.

\section{END NOTES}

1. Mara Naman's interesting and inspiring article about Mona Simpson's The Lost Father inspires me with the main idea of this chapter and gives me the thematic methodology of how to combine or mix these two texts together by using the process of keen search or "pilgrimage." For more details see the whole article "Invisible Ethnic: Mona Simpson and the space of the Ethnic Literature Market."

2. Our selected author, Mona Simpson, is skillfully managed to handle the idea of a broken American family throughout her two novels: Anywhere But Here (that deals with the idea of an outlaw mother who is physically present but emotionally and psychologically absent), and its sequel The Lost Father (which traces the image of the gone away father who is physically, emotionally, and psychologically absent). So, Simpson's protagonists have the two images. The teenager Ann has an outlaw mother and then the adult Mayan has an absent father. Hence, they have lost mother and father as well. How poor characters are Ann and Mayan?!

\section{REFERENCES}

Abdelrazik, Amal Talaat, Contemporary Arab American Women Writers: Hyphenated Identities and Border Crossings. New York: Cambria Press, 2007.

Abinader, Elmaz. Children of Roojme: A family's Journey. New York: Norton, 1991.

Alsultany, Evelyn. "Los Intersticios: Recasting Moving Selves." This Bridge We Called Home: Radical Visions for Transformation. Eds. Gloria E. Anzaldua and Analouise Keating. New York: Routledge, 2002. pp. 106-10.

Amireh, Amal. "Writing the Difference: Feminists' Invention of the "Arab Woman." Interventions Feminist Dialogues on Third World Women's Literature and Film. New York: Garland Publishing INC., 1997.

Bhabha, Homi K. The Location of Culture. London: Routledge, 1994.

Cochran, Lynn. "Unbecoming Gender in the Fiction of Anne Tyler, Mona Simpson, and Sue Miller." Unpublished Diss. (Ph.D.). UMI Number: 9623907. Indiana University, 1996.

Halaby, Laila. "Browner Shades of White" Food for Our Grandmothers: Writings by Arab-American and Arab-Canadian Feminists. Boston: South End Press, 1994. pp. $204-5$.

. "Home." My Name on His Tongue. Syracuse, New York: Syracuse University Press, 2012.

. "The Journey." My Name on His Tongue. Syracuse, New York: Syracuse University Press, 2012.

Heller, Dana A. "Radical Departure: The Feminzation of Quest-Romance.” Unpublished Diss. (Ph.D.). UMI Number: 9820980. The City University of New York, 1989.

Hoyt. Heather Marie. "An "I" for Intimacy Rhetorical Appeal in Arab American Women's Literature." Unpublished Diss. (Ph.D.). UMI Number: 3220303. Arizona State University, 2006.

Jarmakani, Amira. "Arab American Feminisms: Mobilizing the Politics of Invisibility." Arab and Arab American Feminisms: Gender Violence and Belonging. Eds. Rabab, Abdulhadi, Nadine Naber, and Evelyn Alsultany. Syracuse, NY: Syracuse University Press, 2010.

Majaj, Lisa Suhair. "Arab American Literature and the Politics of Memory." Memory and Cultural Politics: New Approaches to American Ethnic Literature. Ed, Amritjit Singh, Joseph T. Skerret, Jr., and Robert E. Hogan. Boston: Northeastern UP, 1996. pp.266-90.

_ duction." Intersections: Gender, Nation, and Community in Arab Women's Novels. Lisa Suhair Majaj, Paula W. Sunderman, and Therese Saliba, eds. Syracuse: Syracuse University Press, 2002. pp. xvii-xxx.

Naber, Nadine. "Resisting the Shore." This Bridge We Called Home: Radical Visions for Transformation. Eds. Gloria E. Anzaldua and Analouise Keating. New York: Routledge, 2002. pp. 301-3.

Naman, Mara. "Invisible Ethnic: Mona Simpson and the space of the Ethnic Literature Market." The Edinburgh Companion to the Arab Novel in English: The Politics of Anglo Arab and Arab American Literature and Culture. Nouri Gana, ed. Edinbrugh: Edinbrugh University Press Ltd., 2013. 
Orfalea, George. "The Arab American Novel." MELUS, Vol. 31 No. 4, Arab American Literature (winter, 2006). pp. 115-133 stable URL: http://www.jstor.org/stable/30029685 accessed 12/06/2014 17:01

Phillips, Robert. "Making Sense of What Takes Place Billie Dyer and Other Stories by William Maxwell: Scar lover by Harry Crews: Life Force by Fay Weldon: Daughters of Albion by A.N, Wilson: The Lost Father by Mona Simpson: Outer bridge Reach by Robert Stone." The Hudson Review, vol. 45. No. 3 (Autumn, 1992). pp. 491-98. URL: http://www.jstor.org/stable/3851760 Accessed: 12/06/2014 17:02

Salaita, Steven. Arab American Literary Fictions, Cultures, and Politics. New York: Palgrave Macmillan, 2007.

Modern Arab American Fiction: A Reader's Guide. Syracuse: Syracuse university press, 2011.

Simpson, Mona. "Anywhere." The North American Review, vol. 271, No. 2 (Jun., 1986), pp. 57-64. URL: http://www. jstor.org/stable/25124738 Accessed: 10/02/2014 01:08
. Anywhere But Here. New York: Vintage Contemporaries Edition, 1992.

. The Lost Father. New York: Knopf, 1992.

Smith, Carlton., and Deborah Paes de Barros. "Singing in the (Post-Apocalyptic) Rain: Some High/Low Notes on Post/postmodernism and Contemporary American Fiction." American Studies International, Vol. 33, No. 1 (April 1995), pp. 1-18 URL: http://www.jstor.org/stable/41280844 Accessed: 11/06/2014 17:09

Smyth, Jacqui Marie. "Other Frontiers: Female Vagrants and Mother Outlaws in American Literature and Film of the 1980s." Unpublished Diss. (Ph.D.). UMI Number: 0591. University of Western Ontario, 1995.

Wittstein, Sandra Shor. "The Effects of Paternal Abuse and Abandonment on a Daughter's Psychological Development: The Father-Daughter Relationship in Two Contemporary American Novels." Unpublished Diss. (Ph.D.). UMI Number: 9629573. The Union Institute Graduate School, 1996. 